\title{
New value determinants to expand the scope of traditional patent valuation methodologies
}

\section{Nuevos determinantes de valor para ampliar el alcance de las metodologías tradicionales de valuación de patentes}

ALONSO-CALPEÑO, Mariela Juana †ै, PÉREZ-JIMÉNEZ, Carlos and CELIS-FLORES, Miguel Ángel

\author{
Instituto Tecnológico Superior de Atlixco \\ Universidad Popular Autónoma del Estado de Puebla
}

ID $1^{\text {st }}$ Author: Mariela Juana, Alonso-Calpeño / ORC ID: 0000-0001-7276-1923.

ID $1^{\text {st }}$ Coauthor: Carlos, Pérez-Jiménez / ORC ID: 0000-0002-8584-9569, CVU CONACYT ID: 87058

ID $2^{\text {nd }}$ coauthor: Miguel Ángel, Celis-Flores / ORC ID: 0000-0002-2209-7849, CVU CONACYT ID: 26288

DOI: $10.35429 / J A F .2019 .19 .6 .1 .8$

Received September 20, 2019; Accepted November 29, 2019

\begin{abstract}
The aim of this investigation is to identify determinants of value considered in the proposals which have emerged during 2013-2018 regarding patents valuation, and to stablish if these elements appeared as proposals to eliminate the limitations that the classic valuation methods could present. The methodology used includes a review in the Web of Science and EBSCOhost databases using keywords; first, to identify whether there were authors who mentioned limitations in classical quantitative valuation methods, such as cost, market and income; later, to recognize if they addressed any of these limitations through new indicators. The results show that the new approaches do possitively address the limitations detected in the so-called classic valuation methodologies; we found 42 indicators for valuing intellectual property, 11 of which are the most mentioned in new proposals. These results contribute to the patent valuation process, by expanding the range of indicators used to determine their value.
\end{abstract}

Valuation methods, Valuation of patents, Valuation indicators

\begin{abstract}
El objetivo de esta investigación es identificar los determinantes de valor que se consideran en las propuestas que han surgido durante el periodo 2013 a 2018 respecto a la valuación de patentes, y establecer si estos surgieron como propuestas para eliminar las limitantes que pudieran presentar los métodos clásicos de valuación. La metodología utilizada, incluye una revisión en las bases de datos de Web of Science y EBSCOhost utilizando palabras clave; primero, para identificar si había autores que mencionaban deficiencias en los métodos de valuación cuantitativos clásicos, como los de costo, mercado e ingreso; después, para reconocer si abordaban alguna de esas limitantes a través de nuevos indicadores o elementos. Los resultados muestran que los nuevos planteamientos sí abordan las limitantes detectadas en las denominadas metodologías clásicas de valuación, se encontró un total de 42 indicadores para valuar propiedad intelectual, de los cuales 11 son los que más se mencionan en las nuevas propuestas. Estos resultados contribuyen al proceso de valuación de patentes, al ampliar el abanico de indicadores utilizados para determinar su valor.
\end{abstract}

Métodos de valuación, Valuación de patentes, Indicadores para valuación

Citation: ALONSO-CALPEÑO, Mariela Juana, PÉREZ-JIMÉNEZ, Carlos and CELIS-FLORES, Miguel Ángel. New value determinants to expand the scope of traditional patent valuation methodologies. Journal of Administration and Finance. 2019, 6-19: $1-8$

*Correspondence to Author (email: mariela.alonso@itsatlixco.edu.mx)

$\dagger$ Researcher contributing first author. 


\section{Introduction}

With the emergence of the knowledge-based economy, the main value-generating activities in organizations are in the field of intangible assets (Pärs and Sander, 2015). An intangible asset is an asset without physical substance which is expected to offer economic benefits in the future (Lagrost, Martin, and Dubois, 2010; Pareja Vasseur and Cadavid Pérez, 2016; Pärs and Sander, 2015). These economic benefits may be present in income on the sale of products or services, cost savings or increased productivity (Astudillo M., Marcela; Mancilla R., 2014).

Within the concept of intangible assets, intellectual property (IP) is a priority, with commercial profit and competitive advantage. The IP has 2 classifications: copyright and industrial property, the latter includes patents, trademarks, industrial designs, utility models and geographical indications (Pareja Vasseur and Cadavid Pérez, 2016).

Patents are exclusive rights granted to an invention, which can be products or processes that provide new ways of doing something or offer a new technical solution to a problem. Patents apply to inventions and deal with how things are made, what they are made of, what they do and how they do it (Saaranto, 2016). The relevance of patents in organizations is that they are indicators of productivity and creativity. Therefore, they are considered a source of added value (Pareja Vasseur and Cadavid Pérez, 2016), since they are used as a substitute for the invention in which their value is recognized (Smith and Cordina, 2015).

Thus, it is important that its economic value be determined (Grimaldi, Cricelli, and Rogo, 2017). The concept of the value of patents refers to the ability to support the process of value creation of the company and its strategic business objectives (Grimaldi et al., 2017), so they are considered elements that must be managed with precision and included in the general corporate and commercial strategy (Soranzo, Nosella, and Filippini, 2017). The importance of patent valuation has grown rapidly, since technological transactions are increasing with the objective of transferring and commercializing the Research and Development (R\&D) results generated both in the productive sector and in the academic sector (Kim, Kim, and Kim, 2015).
Through the transfer, IP rights are formally transmitted to third parties, and therefore, valuation is preponderant (Pérezhernández and Calderón-martínez, 2014), since by assigning an economic and market value, the economic benefit to be obtained can be calculated through the various legal figures through which it can be transferred (Kjellberg \& Mallard, 2013).

The existing literature is relatively rich in different valuation methods and in discussion that relates to various components of its value. Quantitative and qualitative approaches are mentioned (Saaranto, 2016; Soranzo et al., 2017). Within the quantitative three basic approaches are: cost based, market based, and income based (Lagrost et al., 2010; Wirtz, 2012). Also, methods have been developed from them (Allenby, Brazell, Howell, and Rossi, 2014; Collan, Fedrizzi, and Luukka, 2013; Collan and Heikkilä, 2011; Jun, Park, and Jang, 2015; Kim et al., 2015; Kopczewska and Kopyt, 2014; Thoma, 2013).

But there is no unified and/or shared approach to IP valuation (Odasso, Prati, \& Scellato, 2014; Saaranto, 2016). There are only methods and approaches that are more or less suitable for certain types of IP (Lagrost et al., 2010; Saaranto, 2016). As a result, we present the following questions: why, if the range of patent valuation methodologies is so wide, are new approaches emerging to carry out this process? Are there limitations to the application of the classical valuation methods that drive this emergence? What are these limitations? Are the new approaches based on classical methods and only rethink using new elements or indicators to set the value of a patent? What are these elements and indicators on which the determination of the value of a patent is based?

Based on these questions, this paper aims to identify the determinants of value which are considered in the proposals arisen during the period 2013 to 2018 regarding patent valuation and establish whether these emerged as proposals to eliminate the limitations that classic valuation methods could present. 
For this, a review of the literature was carried out in the Web of Science and EBSCOhost databases using keywords; first, to identify whether there were authors who mentioned deficiencies in classical quantitative valuation methods, such as those of cost, market and income; then, to recognize if they addressed any of these deficiencies through new indicators or elements.

The content of the document is divided into four sections: the first deals with the context of the valuation and the approaches associated with it. The following addresses the research methodology used. In the third, the analysis of the results obtained, and finally the conclusions derived from this investigation.

\section{Patent valuation: Importance and implications}

Knowing how much an asset is worth and what determines that value is a prerequisite for making intelligent decisions regarding economic or strategic transactions (Mazzariol and Thomas, 2016). This implies performing a functional analysis that should identify all the factors that contribute to value creation (Casarrubio, 2017). The valuation of patents is important in two ways: one prior to obtaining the patent (Soranzo et al., 2017), since it is desirable to understand the commercial value of the technology and the dynamics of the prospective market before drafting the claims of the patent, because its value depends on the scope of its claims, (Weckowska, 2015); and another, regarding its commercialization (Soranzo et al., 2017), that is, if it is feasible to be commercialized and if it has interest for the market (Allenby et al., 2014).

For the valuation of patents it is necessary to consider, among others, aspects such as the purpose of the valuation, the moment, the competition, the method to be used (Sung, Jun, Kim, and Park, 2017), factors and risks that affect the value of the patent from the economic, legal and technical context (Svačina, 2015). Also, that the price of the license is treated as the value of a patent and, at the same time, as a reward for the depreciation of this asset (Kopczewska \& Kopyt, 2014); this makes it a process in which the identification of its drivers continue to represent key challenges (Kim et al., 2015; Lee et al., 2016; Odasso et al., 2014; Svačina, 2015).

\section{Valuation Approaches}

From the theoretical point of view, the most precise methods to value intangible assets, such as patents, can be divided into two: qualitative and quantitative.

Qualitative methods can be used to assist in the decision-making process regarding the company's IP strategy, or to understand the position of the IP asset portfolio in line with the competitive landscape (Lagrost et al., 2010). They are achieved using assessments based on ratings or value indicators. On the other hand, quantitative methods can be used to give monetary value to assets. As monetary evaluation is often the objective, quantitative methods are more widespread (Pärs and Sander, 2015).

\section{Quantitative Valuation Methods}

Three classical methods of quantitative valuation are predominantly used: the costbased, market-based and income-based methods (Wirtz, 2012), although the option-based approach is also used to a lesser extent (Pärs and Sander , 2015). The cost method is based on the principle that there is a link between the costs incurred during the development of an intellectual property asset and the final value of this asset, as well as the economic principles of replacement and price equilibrium.

They include two techniques: historybased and future-based (Lagrost et al., 2010; Pärs and Sander, 2015; Saaranto, 2016; Wirtz, 2012). Among the most used types of costs are those of reproduction cost, replacement or replacement method, prevention costs and trends in historical costs. The method can be applied to value the intangible asset when it is at an initial level of development and therefore its market is not very clear; the level of uncertainty is high and knowledge of future business is very limited (González, 2011). In the case of the marketbased approach, the value of intangibles is evaluated based on transactions with similar assets. This method can only be used if there are enough transactions with the similar asset in the recent past between unrelated parties, and the price information of these exchanges is available to the public. However, these conditions are generally not met (Pärs and Sander, 2015). 
The income-based method attempts to calculate the present value of the flow of projected future revenues that arise from the object of IP during its expected economic life (Lagrost et al., 2010). It is suitable for investors, since they prefer to know how much intellectual property will generate in the future, how large is the risk involved in the investment and how soon the cash flows will pay for the investment (Saaranto, 2016).

\section{Qualitative valuation methods}

Qualitative valuation can be used to highlight the strategic relevance of a patent based on several considerations, such as information on the current and potential business environment, the legal strength of a patent, the relative importance in its technological field and, finally, the effectiveness of its exploitation strategy (Soranzo et al., 2017). The qualitative approach evaluates intellectual property assets using indicators that are important in the strategy or management of the company (Saaranto, 2016). One of the main criticisms often made regarding the qualitative method is its subjectivity (Lagrost et al., 2010).

It should be noted that even when a quantitative assessment is performed, the results of the qualitative assessment of a technology are referenced anyway. For example, when it comes to fundamental technology and improvement technology, differences should always be observed in the results of their quantitative assessment (Ishii, 2016).

\section{Methodology}

Because this research seeks to contribute to the patent valuation process, by broadening the range of indicators used to determine its value, we should first determine if restrictions were identified in the literature that limited the application of cost-based methods, markets, and income; and second, if they make a proposal to address them, and identify new determinants they propose to achieve it.

For this purpose, the literature review focused on the Web of Science and EBSCOhost databases, in order to retrieve scientific articles with diverse approaches and contexts, using keywords (Table 1).
To identify whether the literature mentioned limitations on the scope of application of classical quantitative valuation methods, scientific articles were considered as of 2010. To recognize whether they addressed any of these limitations through a proposal, and by what new determinants posed to do so, publications were analyzed in the period between 2013 and 2018.

\begin{tabular}{|c|c|c|}
\hline Database & Subject & Key words \\
\hline \multirow{3}{*}{$\begin{array}{l}\text { Web of } \\
\text { Science \& } \\
\text { EBSCOhost }\end{array}$} & $\begin{array}{l}\text { Valuation } \\
\text { methods }\end{array}$ & $\begin{array}{l}\text { Valuation methods; } \\
\text { Valuation methods AND } \\
\text { patents } \\
\text { Valuation methods AND } \\
\text { portfolio patent; valuation } \\
\text { methods AND technology }\end{array}$ \\
\hline & $\begin{array}{l}\text { Intangible } \\
\text { assets }\end{array}$ & $\begin{array}{l}\text { Intangible assets AND } \\
\text { valuation; } \\
\text { Intangible assets AND } \\
\text { patent; valuation AND } \\
\text { methods AND intangible } \\
\text { assets }\end{array}$ \\
\hline & Patents & $\begin{array}{l}\text { Patents AND valuation; } \\
\text { Patents AND portfolio } \\
\text { AND (valuation OR } \\
\text { value); methods AND } \\
\text { (valuation OR value) } \\
\text { AND patents }\end{array}$ \\
\hline
\end{tabular}

Table 1 Search strategy

For the discrimination of publications, the abstracts, the mentioned problem and the objective were analyzed. A second filter consisted in recognizing if they identified limitations on the scope of the classical methods, if they proposed something to solve it, and subsequently, what method they implemented to solve it.

\section{Results}

In the initial search, 86 articles were retrieved. In the first phase of the analysis that consisted of recognizing the limits of scope in the classical quantitative methods of valuation, of those 86 , 23 were used. For the second phase of the study, which consisted of reviewing the proposals of new methods to value patents and establish whether they focused on resolving any of the limitations previously identified, and how they proposed to achieve it, 13 articles were obtained.

\section{Analysis of results}

In the first phase of the analysis, we obtained the results shown in Table 2 . 


\begin{tabular}{|c|c|c|c|}
\hline \multicolumn{4}{|c|}{ Iethods with quantitative approach } \\
\hline & ost-based & Market-based & $\begin{array}{l}\text { Income- } \\
\text { based }\end{array}$ \\
\hline $\begin{array}{l}\text { Value } \\
\text { deter } \\
\text { mina } \\
\text { nts }\end{array}$ & $\begin{array}{l}\text {-Play Costs } \\
\text { - Replacement } \\
\text { costs } \\
\text {-Physical } \\
\text { appreciation } \\
\text {-Functional } \\
\text { obsolescence }\end{array}$ & $\begin{array}{l}\text {-Offer and } \\
\text { demand of the } \\
\text { active market } \\
\text {-Similar and } \\
\text { comparable } \\
\text { transactions } \\
\text {-A multiplier to } \\
\text { transfer } \\
\text { important prices }\end{array}$ & $\begin{array}{l}\text {-Future cash } \\
\text { flow. } \\
\text {-Duration of } \\
\text { cash flow } \\
\text {-Appropriate } \\
\text { discount rate, } \\
\text { which } \\
\text { considers the } \\
\text { risk involved } \\
\text { with the cash } \\
\text { flow }\end{array}$ \\
\hline $\begin{array}{l}\text { Reach } \\
\text { limita } \\
\text { tions }\end{array}$ & $\begin{array}{l}\text {-It may be } \\
\text { difficult to } \\
\text { estimate } \\
\text { indirect costs } \\
\text {-It is } \\
\text { complicated if } \\
\text { the expenses } \\
\text { do not appear } \\
\text { separately in } \\
\text { the financial } \\
\text { statements } \\
\text {-It is not } \\
\text { related to any } \\
\text { market value } \\
\text {-Does not } \\
\text { evaluate } \\
\text { future benefits } \\
\text { arising from } \\
\text { the asset (does } \\
\text { not confirm } \\
\text { that it will } \\
\text { acquire value). }\end{array}$ & $\begin{array}{l}\text {-It cannot be } \\
\text { applied in cases } \\
\text { of unique assets. } \\
\text {-There is limited } \\
\text { information } \\
\text { about } \\
\text { transactions and } \\
\text { trade secrets. } \\
\text {-It is a challenge } \\
\text { to find similar IP } \\
\text { assets. } \\
\text {-To ensure that } \\
\text { market } \\
\text { transactions are } \\
\text { comparable, } \\
\text { sufficient } \\
\text { information is } \\
\text { needed on the } \\
\text { prices, scope } \\
\text { and terms and } \\
\text { conditions } \\
\text { related to the } \\
\text { exchange or sale } \\
\text { of the IP asset. }\end{array}$ & $\begin{array}{l}\text {-It may be } \\
\text { difficult to } \\
\text { project a } \\
\text { reasonable } \\
\text { future cash } \\
\text { flow. } \\
\text {-It is difficult } \\
\text { to predict the } \\
\text { probability of } \\
\text { success or } \\
\text { evaluate the } \\
\text { risk, since } \\
\text { there is no } \\
\text { standard } \\
\text { value for } \\
\text { these } \\
\text { technologies. }\end{array}$ \\
\hline
\end{tabular}

Table 2 Determinants of value and limitations of the classical methods of patent valuation that use the quantitative approach

Source: Prepared by the authors from (Drivas \& Panagopoulos, 2016; Grimaldi et al., 2017; HernándezGarcía, Güemes-Castorena, \& Ponce-Jaramillo, 2018; Ishii, 2016; Kim et al., 2015; Kopczewska \& Kopyt, 2014; Lagrost et al., 2010; Lawryshyn, Collan, Luukka, \& Fedrizzi, 2017; Pärs \& Sander, 2015; Saaranto, 2016; Wirtz, 2012)

The results of this analysis agree with what authors such as Kjellberg \& Mallard, (2013) mention about the need for more multidimensional, dynamic and understandable methods and metrics to capture their characteristics.

Based on this information, a classification was implemented of the limitations addressed by the different authors, with respect to the three classical valuation methods mentioned above in Table 1. The information is shown in Table 3.

\begin{tabular}{|l|l|l|}
\hline \multicolumn{3}{|c|}{ Aspects not included in the scope of the cost-based } \\
method
\end{tabular}

Table 3 Authors who have addressed some of the aspects not considered in the cost-based valuation methods

Table 4 shows the limitations indicated in the quantitative method based on the market, which are being addressed in new proposals for valuation methods.

Finally, Table 5 shows those that refer to quantitative methods based on income. In them, it can be noted that although not all the limitations of each quantitative method have been covered, they have begun to be resolved in order to broaden their scope.

Likewise, it can be observed that Angelis et al., (2014) has addressed limitations indicated in the three classic methods (cost-based, marketbased and income-based). Also, 7 of the 12 authors have focused on the gaps left by incomebased methods, with greater emphasis on projecting a reasonable future cash flow. It is also observed that the least tackled method is cost-based.

\begin{tabular}{|c|c|c|c|c|}
\hline \multicolumn{5}{|c|}{ Aspects not included in the scope of the market-based method } \\
\hline Authors & $\begin{array}{l}\text { It cannot } \\
\text { be } \\
\text { applied } \\
\text { in cases } \\
\text { of single } \\
\text { assets }\end{array}$ & $\begin{array}{l}\text { There is } \\
\text { limited } \\
\text { informat } \\
\text { ion } \\
\text { about } \\
\text { transacti } \\
\text { ons and } \\
\text { trade } \\
\text { secrets }\end{array}$ & $\begin{array}{l}\text { It is a } \\
\text { challeng } \\
\text { e to find } \\
\text { similar } \\
\text { IP assets }\end{array}$ & $\begin{array}{l}\text { To ensure that } \\
\text { market } \\
\text { transactions are } \\
\text { comparable, } \\
\text { sufficient } \\
\text { information is } \\
\text { needed on the } \\
\text { prices, scope and } \\
\text { terms and } \\
\text { conditions related } \\
\text { to the exchange or } \\
\text { sale of the IP asset. }\end{array}$ \\
\hline $\begin{array}{l}\text { (Angelis et al., } \\
2014 \text { ) }\end{array}$ & $\mathrm{X}$ & & & \\
\hline \begin{tabular}{ll}
\multicolumn{2}{l}{ Kopczewska } \\
$\&$ & Kopyt, \\
$2014)$ & \\
\end{tabular} & & & $X$ & \\
\hline $\begin{array}{l}\text { (Svačina, } \\
2015)\end{array}$ & & & & $\mathrm{X}$ \\
\hline $\begin{array}{l}\text { (Sung, Jun, } \\
\text { Kim, \& Park, } \\
\text { 2017) }\end{array}$ & & $\mathrm{X}$ & $\mathrm{X}$ & $\mathrm{X}$ \\
\hline
\end{tabular}

Table 4 Authors who have addressed some of the aspects not considered in market-based valuation methods 
Subsequently, we prepared a classification of the value determinants that the authors add to their proposals to determine the economic value of the patents. 42 value determinants were identified and also a convergence of the different authors towards 12 main ones. These are shown in Table 6.

\begin{tabular}{|c|c|c|c|}
\hline \multicolumn{4}{|c|}{$\begin{array}{l}\text { Aspects not included in the scope of the income- } \\
\text { based method }\end{array}$} \\
\hline Authors & $\begin{array}{l}\text { It can be } \\
\text { difficult to } \\
\text { project a } \\
\text { reasonable } \\
\text { future cash } \\
\text { flow }\end{array}$ & $\begin{array}{l}\text { It is difficult to } \\
\text { predict the } \\
\text { probability of } \\
\text { success or assess } \\
\text { the risk, since there } \\
\text { is no standard value } \\
\text { for these } \\
\text { technologies }\end{array}$ & $\begin{array}{l}\text { It is not easy } \\
\text { to guarantee } \\
\text { the } \\
\text { objectivity } \\
\text { of the } \\
\text { valuation } \\
\text { results. }\end{array}$ \\
\hline $\begin{array}{l}\text { (Angelis } \\
\text { et al., 2014) }\end{array}$ & & 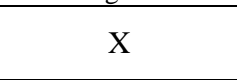 & \\
\hline $\begin{array}{ll}\text { (Jun, } & \text { Park, } \\
\& & \text { Jang, } \\
2015) & \end{array}$ & $X$ & & $X$ \\
\hline $\begin{array}{ll}\text { Kim, } & \text { Kim, } \\
\& & \text { Kim, } \\
2015) & \\
\end{array}$ & & $X$ & \\
\hline $\begin{array}{l}\text { (Russell, } \\
2016)\end{array}$ & & $X$ & \\
\hline $\begin{array}{l}\text { (Grimaldi, } \\
\text { Cricelli, \& } \\
\text { Rogo, 2017) }\end{array}$ & $X$ & & \\
\hline $\begin{array}{l}\text { (Lawryshyn, } \\
\text { Collan, } \\
\text { Luukka, \& } \\
\text { Fedrizzi, } \\
\text { 2017) }\end{array}$ & $X$ & & \\
\hline $\begin{array}{l}\text { (Hernández- } \\
\text { García, } \\
\text { Güemes- } \\
\text { Castorena, } \\
\text { \& Ponce- } \\
\text { Jaramillo, } \\
\text { 2018) }\end{array}$ & $X$ & & \\
\hline
\end{tabular}

Table 5 Authors who have addressed some of the aspects not considered in income-based valuation methods

\begin{tabular}{|l|l|r|}
\hline \multicolumn{2}{|c|}{ Indicator } & \multicolumn{1}{|c|}{ Total } \\
\hline 1 & Expiry time & 6 \\
\hline 2 & Citations & 5 \\
\hline 3 & International Patent Classification Code / IPC) & 5 \\
\hline 4 & Claims & 5 \\
\hline 5 & R\&D cost & 5 \\
\hline 6 & Territory (market size) & 4 \\
\hline 7 & Compound annual growth rate of the market & 3 \\
\hline 8 & Technological area & 2 \\
\hline 9 & Patent number in the portfolio & 2 \\
\hline 10 & Portfolio Size & 2 \\
\hline 11 & Technology cycle time & 2 \\
\hline 12 & Marketing time & 2 \\
\hline
\end{tabular}

Table 6 Convergence of authors towards the mention of value determinants

Source: Prepared by the authors from (Angelis, Ford, \& Dillard, 2014, Kopczewska \& Kopyt, 2014, Odasso et al., 2014, Jun et al., 2015, Kim et al., 2015, Svačina, 2015, Thoma, 2015, Yoo, Kim, \& Jeong, 2015, Lee et al., 2016, Russell, 2016, Chang \& Fan, 2017, Grimaldi et al., 2017, Sung et al., 2017).
As it can be seen, of 12 authors, 6 position as the most important determinant the expiry time, since they represent $46 \%$ of the mentions. It can also be observed that these indicators are related to qualitative methods, specifically in the approach of value indicators, such as number of references to previous patents generated during the search process, number of citations, number and quality of claims, the size of the family of patents (Lagrost, Martin, \& Dubois, 2010), applicants, inventors, international patent classification code (IPC), geographical extension of the patent, and abstracts of inventions (Grimaldi et al., 2017), among others.

All this allows us to infer that the methods that are being generated include a mixed approach. And, although according to Ishii (2016), by linking the results of the qualitative assessment with those of the quantitative assessment a new challenge difficult to address regarding how qualitative properties can be quantified will arise, these proposals are solving it from that perspective.

\section{Conclusions}

According to the objective set out in this investigation, which was to identify the value determinants considered in the proposals during the period 2013 to 2018 regarding the valuation of patents, it has been shown that 12 indicators were considered -expiry time, citations, IPC, claims, R\&D costs, market size, compound annual growth rate of market, technological area, patent number in the portfolio, portfolio size, technological cycle time, and marketing time- to determine the patent value, and that this provides flexibility to that process.

It can be asserted that the proposed methods have emerged as a response to eliminate the limitations that the classical valuation methods might present. Likewise, it is evident that they continue to develop in order to resolve the absence of a shared approach to determine their economic value.

Thus, it can be deduced that there has been a breakthrough in the subject, but also that the orientation of value determination is migrating towards a mixed approach. 
It is inferred that the research work on the subject will continue to be approached from different perspectives and contexts, in order to find the economic value of the patents and obtain the maximum benefit when going to market. This review has not been exhaustive, since only articles available in the aforementioned data sources were consulted, and we only contemplated a period of five years.

\section{References}

Allenby, G. M., Brazell, J., Howell, J. R., \& Rossi, P. E. (2014). Valuation of Patented Product Features. The Journal of Law and Economics, 57(3), 629-663. https://doi.org/10.1086/677071

Angelis, D. I., Ford, D. N., \& Dillard, J. T. (2014). Valuation of Real Options as Competitive Prototyping in System Development. Defense AR Journal, 21(3), 668692. Retrieved from https://calhoun.nps.edu/bitstream/handle/10945/ 45407/ARJ-70_Angelis.pdf?sequence $=1$

Astudillo M., Marcela; Mancilla R., M. E. (2014). La valuación de los bienes intangibles en México. Actualidad Contable FACES Año 17, 9(33), 45-60. Retrieved from http://www.redalyc.org:9081/articulo.oa?id=25 731098002

Casarrubio, B. P. (2017). Tratamiento de los activos intangibles. Retrieved from https://repositori.upf.edu/bitstream/handle/1023 0/33175/BorjaPascualTFG.pdf? sequence $=1 \&$ is Allowed=y

Chang, S.-H., \& Fan, C.-Y. (2017). A new model for measuring the impact of patent value growth trajectory. International Journal of Technology, Policy and Management, 17(1), 40-57. https://doi.org/10.1504/IJTPM.2017.083742

Collan, M., Fedrizzi, M., \& Luukka, P. (2013). Expert Systems with Applications A multiexpert system for ranking patents : An approach based on fuzzy pay-off distributions and a TOPSIS - AHP framework, 40, 4749-4751.

Collan, M., \& Heikkilä, M. (2011). Enhancing patent valuation with the pay-off method. Journal of Intellectual Property Rights, 16(5), 377-384.
Drivas, K., \& Panagopoulos, A. (2016). Using the patent term changes in assessing the evolution of patent valuation from filing to maturity. European Journal of Innovation Management, 19(4), https://doi.org/10.1108/EJIM-04-2015-0027

González, P. (2011). Una Aproximación a Un Modelo De Decisión Para Valorar Activos Intangibles Basados En Tecnología: Caso Estudio Compañía De Software Colombia S.a. Revista Universo Contábil, 7(1), 106-121. https://doi.org/10.4270/ruc.2011107

Grimaldi, M., Cricelli, L., \& Rogo, F. (2017). Valuating and analyzing the patent portfolio: the patent portfolio value index. European Journal of Innovation Management. https://doi.org/10.1108/EJIM-02-2017-0009

Hernández-García, R. D., Güemes-Castorena, D., \& Ponce-Jaramillo, I. E. (2018). A real option based model for the valuation of patent protected technological innovation projects. World Patent Information, 53(March), 24-38. https://doi.org/10.1016/j.wpi.2018.05.002

Ishii, Y. (2016). Valuation of intellectual property. Tokyo. https://doi.org/10.1108/14691930510611094

Jun, S., Park, S., \& Jang, D. (2015). A Technology Valuation Model Using Quantitative Patent Analysis: A Case Study of Technology Transfer in Big Data Marketing. Emerging Markets Finance and Trade, 51(5), 963-974.

https://doi.org/10.1080/1540496X.2015.106138 7

Kim, J., Kim, J., \& Kim, S.-K. (2015). A Patent Valuation Method Using Game Theoretic Real Option Approach. Journal of the Korean Operations Research and Management Science Society, 40(2), 43-61.

Kjellberg, H., \& Mallard, A. (2013). Valuation Studies? Our Collective Two Cents. Valuation Studies, 1(1), 11-30. https://doi.org/10.3384/vs.2001-5992.131111

Kopczewska, K., \& Kopyt, M. (2014). Nonlinear corrections in market method of patent valuation. Business and Economic Horizons, 10(3), 177-190.

https://doi.org/10.15208/beh.2014.15 
Lagrost, C., Martin, D., \& Dubois, C. (2010). Intellectual property valuation: how to approach the selection of an appropriate valuation method. Journal of Intellectual Capital, 11(4), 481-503. https://doi.org/10.1108/EL-01-2014-0022

Lawryshyn, Y., Collan, M., Luukka, P., \& Fedrizzi, M. (2017). New procedure for valuing patents under imprecise information with a consensual dynamics model and a real options framework. Expert Systems with Applications, 86 , 1339-1351. https://doi.org/10.1016/j.eswa.2017.05.056

Lee, J. H., Khee-su, B., Lee, J. W., In, Y., Kwon, T., \& Lee, W. (2016). Valuation method by regression analysis on real royalty-related data by using multiple input descriptors in royalty negotiations in Life Science area-focused on anticancer therapies. Journal of Open Innovation: Technology, Market, and Complexity, 2-21. https://doi.org/10.1186/s40852-016-0047-7

Mazzariol, P., \& Thomas, M. (2016). Theory and practice in M\&amp;A valuations. Strategic Direction, 32(6), 8-11. https://doi.org/10.1108/SD-03-2016-0032

Odasso, C., Prati, V. G., \& Scellato, G. (2014). Selling patents at auction : an empirical analysis of patent value. Industrial and Corporate Change, 24(2), 417-438. https://doi.org/10.1093/icc/dtu015

Pareja Vasseur, J., \& Cadavid Pérez, C. (2016). Valoración de patentes farmacéuticas a través de opciones reales: equivalentes de certeza y función de utilidad. Contaduria y Administracion, 61(4), 794-814. https://doi.org/10.1016/j.cya.2016.06.004

Pärs, M., \& Sander, P. (2015). Valuation practices of intangible assets in Estonia. En In 2nd International Multidisciplinary Scientific Conference on Social Sciences and Arts SGEM2015 (pp. 549-556).

Pérez-hernández, P., \& Calderón-martínez, G. (2014). Análisis de los Procesos de Comercialización de Tecnología en Dos Instituciones de Educación Superior Mexicanas Analysis of the $\mathrm{T}$ echnology $\mathrm{C}$ ommercialization $\mathrm{P}$ rocess in $\mathrm{T}$ wo Mexican $\mathrm{H}$ igher $\mathrm{E}$ ducation $\mathrm{I}$ nstitutions. Journal of Technology Management \& Innovation, 9(3), 196-209.
Russell, M. (2016). The Valuation of Pharmaceutical Intangibles and Drugs Mark Russell The University of Queensland. Journal of Intellectual Capital, 17(3), 484-506. https://doi.org/10.1108/JIC-10-2015-0090

Saaranto, A. (2016). A Review of the Methods for Valuing Intellectual Property Rights. Retrieved from http://sal.aalto.fi/publications/pdffiles/esaa16_public.pdf

Smith, J. A., \& Cordina, R. (2015). Patenting and the early-stage high-technology investor: Evidence from the field. $R$ and $D$ Management, 45(5), 589-605.

https://doi.org/10.1111/radm.12101

Soranzo, B., Nosella, A., \& Filippini, R. (2017). Redesigning patent management process: an Action Research study. Management Decision, 55(6), 1100-1121. https://doi.org/10.1108/MD04-2016-0226

Sung, T.-E., Jun, S.-P., Kim, S.-G., \& Park, H.W. (2017). A Study on Web-based Technology Valuation System. Journal of Intelligence and Information Systems, 23(1), 23-46.

Svačina, P. (2015). An Empirical Analysis of Factors Affecting Prices of Intangible Assets: A Preliminary Testing in Consumer Durables Sector. Prague Economic Papers, 24(3), 354363. https://doi.org/10.18267/j.pep.523

Thoma, G. (2013). Quality and Value of Chinese Patenting: An International Perspective. Seoul Journal of Economics, 26(1), 33-72.

Weckowska, D. M. (2015). Learning in university technology transfer offices: Transactions-focused and relations-focused approaches to commercialization of academic research. Technovation, 41, 62-74. https://doi.org/10.1016/j.technovation.2014.11. 003

Wirtz, H. (2012). Valuation of Intellectual Property: A Review of Approaches and Methods. International Journal of Business and Management, 7(9), 40-48. https://doi.org/10.5539/ijbm.v7n9p40 